\title{
Reframing libel: taking (all) rights seriously and where it leads
}

\author{
Alastair Mullis \\ University of East Anglia \\ ANDREW SCOTT* \\ London School of Economics and Political Science
}

\section{Introduction}

L ibel reform is happening. In 2009, Index on Censorship and English PEN published a sreport in which they lamented the state of English libel law and made recommendations for reform. ${ }^{1}$ Some of these reform proposals were then incorporated into an abortive Defamation Bill sponsored by Lord Lester and debated in the House of Lords in July 2010. The reform baton was taken on by the Ministry of Justice which published a Draft Defamation Bill and consultation paper in March 2011.2 A Joint Committee of Parliament has offered its view, ${ }^{3}$ and it is currently expected that a Defamation Bill proper will be introduced by the government in the second session of this Parliament. ${ }^{4}$ No one seriously contests that there are problems with the existing law and practice of libel. The government draft Bill, like Lord Lester's forerunner however, does little to address the breadth of these problems. There is now a serious risk that the government will miss an historic opportunity to reframe the law so as properly to value and balance personal and social interests in expression, reputation and access to justice. Our basic complaint regarding the reform movement has been that it overemphasises freedom of expression (specifically speakers' interests) to the virtual exclusion of other

* We are indebted to Tor Tarantola for research assistance in support of this paper. We consulted widely on a working paper version, and are immeasurably grateful for the extensive advice and criticism we are received thereon. In particular, we wish to express our gratitude to Tamsin Allen, Jack Anderson, Eric Barendt, Jason Bosland, Alastair Brett, David Capper, John Charney, Rod Christie-Miller, Dominic Crossley, Mike Dodd, Sir David Eady, Nick Emler, Conor Gearty, Sir Charles Gray, Jonathan Heawood, Steve Hedley, David Howarth, Meirion Jones, Gavin Millar QC, Richard Moorhead, Adrienne Page QC, Benjamin Pell, Gill Phillips, Gavin Phillipson, David Price QC, James Price QC, Joshua Rozenberg, Keith Schilling, Adam Speker, Hugh Tomlinson QC and Paul Tweed. All errors, omissions and inanities are attributable to the authors alone.

1 Index on Censorship/English PEN, Free Speech is not for Sale (2009), available at www.libelreform.org/ourreport (accessed November 2010) (hereafter the Index/PEN report).

2 Draft Defamation Bill Consultation, Cm 8020, March 2011, available at www.justice.gov.uk/consultations/draftdefamation-bill.htm (accessed November 2011).

3 Draft Defamation Bill, HL Paper 203, HC 930-I (2010-2012). The report welcomed many of the proposals contained in the government draft Bill, but urged the government to go further in a number of respects.

4 Ministry of Justice, Business Plan 2011-2015, p. 19. 
important values. ${ }^{5}$ In consequence, it is focused in large measure upon revising the substantive law of libel, when the primary problems in this area instead concern procedures and costs (though there are some changes to the substantive law that are desirable). The proposals on the table spectacularly fail to deal with some of the key issues that blight the law of defamation. There is a real risk that the government will produce a Bill that will continue to ignore these concerns.

In preparing this paper, we have returned to first principles and re-evaluated fundamental aspects of libel law, its purposes, its substance and its processes. Our thinking has been informed by, first, philosophical understandings of democracy and the public sphere and in particular the role of freedom of speech and of the media therein, and, second, the social psychology of reputation. By doing this, we are able to ground some of the proposals for reform made previously by Index on Censorship, English PEN, Lord Lester and, most recently, in the government draft Bill. We do so, however, not through the prism of an over-weaned emphasis on freedom of expression, but rather by triangulating the rights and interests of claimants, defendants and the wider public. Ultimately, we recommend a coherent set of significant substantive and procedural reforms that if enacted would enhance access to justice and reduce costs for the vast majority of libel actions.

In essence this involves the recommendation of a two-track libel regime. The first track would involve the establishment of a new approach to libel actions that would emphasise the swift resolution of complaints and the provision of discursive remedies (adding information into the public domain rather than permitting censorship by law). This would be administered by co-regulatory bodies designated under a new Defamation Act. This group would certainly include a self- or statutory media regulator, ${ }^{6}$ but might also extend to expert professional panels (under the auspices of, for example, the British Medical Association or the Royal Society) or independent arbitrators (for example, Early Resolution) for cases arising other than through media publication. ${ }^{7}$ The vast majority of cases would be disposed of by this route. The second track would involve only some aspects of the most serious and/or most damaging libels (claims for special damage or truly egregious psychological harm), and cases where the defendant wished to develop a defence based on the public interest rather than truth. These aspects would be referred out for consideration in the High Court and would see the parties carry their own costs. The High Court could also be asked to review the first-track decisions of the designated bodies.

In the paragraphs that follow, first, we review and develop the principles that should underpin the libel regime. Second, we consider the purposes of libel law and reflect on how the revised understanding of the foundational principles should influence regime design. We conclude by sketching the outlines of a two-track libel regime that is consonant with the underlying principles on which any such regime must be based.

\section{Principles underpinning the libel regime}

The normative foundations of any coherent libel regime must comprise an appropriate valuation of the individual and social importance of freedom of expression, reputation and

5 A Mullis and A Scott, "Something rotten in the state of English libel law? A rejoinder to the clamour for reform of defamation" (2009) 14(6) Communications Law 173-83; “Lord Lester's Defamation Bill 2010: a distorted view of the public interest?" (2011) 16(1) Communications Law 6-19; "Worth the candle? The government's Draft Defamation Bill" (2011) 3 Journal of Media Law 1-17.

6 For recent discussion of the possibility of a media regulator undertaking libel adjudications, see H Tomlinson, "A radical new proposal: Pt 3 - the Media Regulation Tribunal", Inforrm 4 October 2011; A Rushbridger, "After Murdoch's excesses, let us seize the opportunity in the phone hacking inquiry”, The Guardian, 10 November 2011.

7 Further details of Early Resolution are available at www.earlyresolution.co.uk/ (accessed November 2011). 
access to justice. These principles will sometimes be in tension. There is a significant concern that the first of these ideas has come to predominate, and that to the extent that the third principle is discussed this is almost always done to highlight the undoubted "chilling effect" of the existing costs regime on freedom of speech.

\section{TAKING FREE SPEECH SERIOUSLY}

The central importance in a democracy of freedom of expression is universally recognised. It is regularly reiterated by European and domestic courts. ${ }^{8}$ It is a mainstay of liberal political theory. Our thinking has been informed by Habermas' theories of communicative action, discourse ethics and the public sphere, which comprise a seminal contribution to the literature on "deliberative" or "discursive democracy".? The starting point is Habermas" identification of a series of normative standards for human conduct that are implied in every communicative act (the "inescapable presuppositions of speech"). This understanding is then correlated with the depiction of society as composed of "system" and "lifeworld" to offer a two-tiered model of the democratic constitution. The first tier comprises the "public sphere", wherein proceeds the open discussion between disparate citizens, interest groups, organisations and expert commentators of all issues of mutual concern. This is the bedrock of the polity. Obviously, the mass media offers a significant platform for public sphere representations and - to some extent - discussion. In addition, however, "a portion of the public sphere comes into being in every conversation in which private individuals assemble to form a public body". ${ }^{10}$ That is, on every occasion on which people discuss matters of mutual, public concern. On the second level are the legally constituted institutions of government, responsible for the formal transposition of the collective political will into positive law. The role of constitutional critique and scholarship is twofold: to consider the extent to which the constitution allows powerful interlocutors to subvert the integrity of the public sphere, and to assess the coherence of the articulation between the two tiers in terms of both processes and outcomes.

Manifestly, libel law is one aspect of the constitution of the public sphere, and is therefore - notwithstanding its primary focus on the determination of individual interests - an important subject for constitutional critique. There are few people who do not recognise the strictures that the current libel regime can impose on free speech. There is

8 In Steel and Morris $\mathrm{v}$ United Kingdom (2005) 41 EHRR 22, for example, the European Court of Human Rights noted that "[freedom of speech is] one of the essential foundations of a democratic society and one of the basic conditions for its progress and for each individual's self-fulfilment . . applicable not only to 'information' or 'ideas' that are favourably received or regarded as inoffensive or as a matter of indifference, but also to those that offend, shock or disturb. Such are the demands of pluralism, tolerance and broadmindedness without which there is no "democratic society" (at [87]). Similarly, in R v Secretary of State for the Home Department, ex parte Simms [2000] 1 AC 115, Lord Steyn explained that "freedom of expression is, of course, intrinsically important: it is valued for its own sake. But it is well recognised that it is also instrumentally important. It serves a number of broad objectives. First, it promotes the self-fulfilment of individuals in society. Secondly, in the famous words of Holmes J . . 'the best test of truth is the power of the thought to get itself accepted in the competition of the market' . . thirdly, freedom of speech is the lifeblood of democracy. The free flow of information and ideas informs political debate. It is a safety valve: people are more ready to accept decisions that go against them if they can in principle seek to influence them. It acts as a brake on the abuse of power." (at 126)

9 See J Habermas, The Structural Transformation of the Public Sphere: An Inquiry into a category of bourgeois society, T Burger (trans.) (Cambridge: Polity Press 1992); The Theory of Communicative Action. Vol. I - Reason and the rationalisation of society, T McCarthy (trans.) (Boston: Beacon Press 1984); The Theory of Communicative Action. Vol. II - Lifeworld and System: A critique of functionalist reason, T Burger (trans.) (Cambridge: Polity Press 1987); Between Facts and Norms: Contributions to a discourse theory of law and democracy, W Rehg (trans.) (Cambridge: Polity Press 1996).

10 J Habermas, "The public sphere: an encyclopedia article (1964)" (1974) 1(3) New German Critique 49-55, p. 49. 
clearly potential for misuse of libel law to preclude investigative journalism, to stifle scientific and medical debate, to undermine the important work of human rights organisations and other non-governmental organisations, and to invite the strategic legal tourist from abroad. To the extent that the law allows powerful individuals or corporate entities to "chill" important, warranted comment concerning themselves, their activities, their products or their ideas, it is socially dysfunctional. In recognising this potentiality, it is vital to appreciate that it is costs, processes and remedies rather than the substantive law that comprise the key issues to be addressed.

One of the important features of Habermas' work is the contention that rights are considered to be "relational" in origin. They are derived from the fact of society, and are not primarily inherent in individuals. Their importance and value are not just personal or individual; they are also social in character. This is clear as regards freedom of speech in the emphasis placed on the interests of the wider public in the rendition of the standard arguments from democracy and from truth. ${ }^{11}$ It also applies to the rights to privacy and to reputation. Moreover, the potential for divergence between the interests of the media and those of the audiences for its output must not be overlooked. ${ }^{12}$

This suggests a further respect in which the current law of libel does not adequately secure the provision of full and accurate information on matters of public importance. This is its failure sometimes to ensure the correction of error, with the result that the wider public is often left misinformed by false publications. ${ }^{13}$ This situation arises on account of a number of systemic weaknesses. First, limitations on access to justice for claimants can mean that some errors are never challenged. Second, the award of damages alone for vindication does not necessarily highlight mistakes that have been published, ${ }^{14}$ and if apologies and corrections are made this is often done without what might be considered to be due prominence. Third, the manner in which the Reynolds public interest defence currently operates masks the fact that the impugned publication has not been

11 See, generally, E Barendt, Freedom of Speech 2nd edn (Oxford: OUP 2005), ch. 1. These ideas are encapsulated in the comments of Lord Steyn in exparte Simms (see above).

12 This was reflected in the recent comments of Tugendhat J in JIH v News Group Newspapers Ltd [2010] EWHC 2818 (QB) to the effect that "it is not to be assumed that news publishers are always concerned to protect the Art 10 rights of the public" (at [61]). In contrast, it was elided by Lord Lester when acting as chair at the "Reframing Libel" symposium, City University London, 4 November 2010, who explicitly assimilated the media and the public suggesting that their respective interests were entirely mutually held. Revised versions of the papers delivered at the conference, along with an event video are available at http://reframinglibel.com (accessed November 2011).

13 The imperative of making such corrections is recognised in journalists' own statements of professional ethics - see, for example, the PCC Editors' Code of Practice, cl. 1(ii) ("a significant inaccuracy, misleading statement or distortion once recognised must be corrected, promptly and with due prominence, and - where appropriate - an apology published"); NUJ Code of Conduct, cl. 3 ("[a journalist] does her/his utmost to correct harmful inaccuracies") - although it is a common complaint that such principles are much-honoured in the breach. Interestingly, as regards the "Comment is free" section of its website, The Guardian provides an automatic right of reply to any person mentioned in a published article (see www.guardian.co.uk/ commentisfree/series/response). The failure to ensure the correction of misinformation can also be seen as a shortcoming of the American approach to the defamation of public figures. Traditionally, this concern has been addressed by a relatively high and generalised commitment to journalistic ethics that insists upon factchecking and the correction of error. It may be, however, that the inadequacies of this "cultural" form of regulation are exposed when confronted with more "populist" forms of media content such as that reflected in publications such as the National Enquirer, television channels such as Fox News, or the proliferation of online gossip websites.

14 Although cl. 1(iv) of the PCC Editors' Code of Practice provides that "a publication must report fairly and accurately the outcome of an action for defamation to which it has been a party". Libel claims that are settled will often include an agreement that an appropriate correction and/or apology will be published, and sometimes that an apologetic statement in open court will be made. 
demonstrated to be true, and the claimant is left without vindication of reputation. Whether such continuing misinformation is in the public interest can be reasonably questioned. ${ }^{15}$ This need not be the impact of a coherent libel regime. Libel law can be constructed so as to form part of the "discursive constitution". Perhaps paradoxically, it can be so designed as to promote freedom of expression, and to secure the provision to the general public of the fullest possible information on matters of collective importance. Mandated discursive remedies - such as corrections, retractions, and rights of reply could serve these objectives.

\section{TAKING REPUTATION SERIOUSLY}

Some uncertainty surrounds the status of reputation in law. A notable development in Convention jurisprudence concerns the drawing of the concept within the ambit of Article 8 of the European Convention on Human Rights (ECHR). ${ }^{16}$ Yet, reputation - by dint of being determined by aggregating the appraisals made of an individual by other people - is quintessentially public in nature. The emerging caselaw therefore immediately begs the question of how reputation can be protected as an aspect of one's private or family life.

The first strands of this jurisprudence were roundly rejected by some notable commentators. Robertson and Nicol, for example, were categorical in their derision of what they considered to be an "impermissible slight [sic] of hand". ${ }^{17}$ They asserted that the recognition of reputation as a component of Article 8 was the "careless" and "illegitimate" result of "overworked judges and their registrars churning out decisions". 18 They viewed the equation between reputation and privacy as a "brazen", "plainly wrong . . . aberration", and the fruit of European judges" "unprincipled and unprecedented frolics". ${ }^{19}$ Irrespective of this critique, the development has subsequently been confirmed in a number of Strasbourg decisions, and has also been endorsed in domestic jurisprudence. In the first of the European decisions, Lindon, Otchakovsky-Laurens and July v France, an expanded justification for the inclusion of reputation as a component of Article 8 was developed in a concurring judgment. ${ }^{20}$ In Pfeifer $\mathrm{v}$ Austria, the Strasbourg court demonstrated incontrovertibly for the first time, and at some length, how the balancing of Articles 8 and 10 should proceed in defamation actions. ${ }^{21}$ Some subsequent decisions of the European

15 J Coad, "Reynolds and public interest: what about truth and human rights?" (2007) 18(3) Entertainment Law Review 75-85.

16 The first jurisprudential association between the protection of reputation and the right to private life was made only in 2004. In Radio France v France (2005) 40 EHRR 706, the court observed - in a passing reference only - that "the right to protection of one's reputation is of course one of the rights guaranteed by Article 8 of the Convention" (at [31]). Shortly afterwards, in Chauyy v France (2005) 41 EHRR 29, the court proceeded on the basis that the inclusion of an individual's reputation as a value actively protected under Article 8 was routine (at [70]). This shift was subsequently alluded to in a number of further cases - see, for example, Cumpănă and Mazăre v Romania (2005) 41 EHRR 41, at [91]; White v Sweden (2008) 46 EHRR 3, at [26]; Leempoel v Belgium, Application No 64772/01 (unreported, 9 November 2006), at [67]. For discussion of this development, see D Spielmann and L Cariolou, "The right to protection of reputation under the European Convention on Human Rights" in D Spielmann, M Tsirli and P Voyatzis (eds), The European Convention on Human Rights, A Living Instrument: Essays in honour of Christos L Rozakis (Brussels: Bruylant 2011); H Rogers, "Is there a right to reputation?", Inforrm, 26 October 2010 (part one) and 29 October 2012 (part two); A Mullis and A Scott, "The swing of the pendulum: reputation, expression and the re-centring of English libel Law" (2012) 63 NILQ 25.

17 G Robertson and A Nicol, Media Law 5th edn (London: Sweet \& Maxwell 2007), p. 67.

18 Ibid.

19 Ibid. p. 70 .

20 (2008) 46 EHRR 35.

21 (2009) 48 EHRR 8. 
Court, however, have been more equivocal. ${ }^{22}$ Notwithstanding this, the development was considered and affirmed by the Supreme Court in Re Guardian News \& Media Ltd. ${ }^{23}$

None of this caselaw particularly answers the normative question as to quite why a "right to reputation" should be considered to fall within Article 8. There is a persuasive answer, however, and it is to be found in the social psychology canon. ${ }^{24}$ In social psychology, for over one hundred years, it has been absolutely standard, generally accepted knowledge that the opinions of others become incorporated into the individual's sense of self-worth. In 1902, Charles Cooley developed the framework of the "looking-glass self". 25 In 1934, George Herbert Mead described a similar process, and observed that "we are more or less unconsciously seeing ourselves as others see us". ${ }^{26}$ Subsequently, these formulations have been revised somewhat and three components of self-worth have been identified: selfappraisals; the actual appraisals made by others; and the individual's perceptions of the appraisals made by others (or "reflected appraisals"). Interestingly, considerable research indicates that there is a stronger relationship between reflected appraisals and self-appraisal, than between actual appraisals and self-appraisals.

Social psychology tells us that it is primarily the perceived level of esteem that we think others hold for us that affects our judgments of self-worth. Hence, it is not difficult to

22 See, for example, Karako v Hungary, (2011) 52 EHRR 36).

23 [2010] UKSC 1, at [37]-[42], per Lord Rodger. See also, Greene v Associated Newspapers Ltd [2004] EWCA Civ 1462, at [68]; Flood v Times Newspapers Ltd [2010] EWCA Civ 804, at [20]; Thornton v Telegraph Media Group Ltd [2010] EWHC 1414 (QB), at [39]. In Mullis and Scott, "The swing of the pendulum", n. 16 above, we consider a number of different justifications offered by the European Court of Human Rights and the English courts as to why, and when, reputation may fall to be protected by Article 8 . Though the jurisprudence is by no means consistent, nor fully developed, the most convincing justification has been offered in the European Court of Human Right's decision in Karako v Hungary (2011) 52 EHRR 36. In Karako, the court strongly emphasised the variability of Article 8 coverage of reputation. It noted "a clear distinction, ubiquitous in the private and constitutional law of several Member States, between personal integrity and reputation" (at [22]), and that "personal integrity rights falling within the ambit of Article 8 are unrelated to the external evaluation of the individual" (at [23]). Having distinguished harm to an individual's psychological integrity from harm to other people's perceptions, the court explained that only when a libel was sufficiently serious would it be liable to impinge upon personal integrity and hence invoke Article 8 (at [23]). The approach taken by the court in Karako has the merit of clearly differentiating two aspects of reputation. Reputation as it affects personal dignity or psychological integrity, and reputation as property or quasi-property. Moreover, this approach is consistent with the social psychology canon referred to in the text.

24 See, generally, N Emler, "A social psychology of reputation" (1990) 1 European Review of Social Psychology 171-93. Our adoption of this literature is unlikely to be considered exceptional by those who have considered the function and design of defamation law. Professor Eric Barendt's rumination in "What is the point of libel law?" (1999) 52 Current Legal Problems 110-25 made precisely this point, and has been the starting point for much recent reflection. Earlier still, the seminal article on reputation and defamation by Robert Post has also informed much subsequent research - see "The social foundations of defamation law: reputation and the constitution" (1986) 74 California Law Review 691. Post considered that reputation could be understood in different ways, as property, as honour and as dignity. In the last respect, he noted that a person's dignity depends on whether others in the community give him the deference that is his deserts as a full member of society. As he explained, "our own sense of intrinsic self-worth, stored in the deepest recesses of our "private personality' is perpetually dependent upon the ceremonial observance by those around us of rules of defence and demeanor, thereby protecting the dignity of its members" (at 710). He considered that, denied such deference, a person's intrinsic sense of his own self-worth and dignity is diminished. A similar idea was aired by the Marchioness de Lambert in Advice of a Mother to her Son: A tract particularly recommended to bis son by Lord Chesterfield, "the love of esteem is the life and soul of society; it unites us to one another: I want your approbation, you stand in need of mine. By forsaking the converse of men, we forsake the virtues necessary for society; for when one is alone, one is apt to grow negligent; the world forces you to have a guard over yourself.", in Practical Morality, or, a Guide to Men and Manners (Hartford: William Andrus 1841), p. 155.

25 C Cooley, Human Nature and the Social Order (New York: Scribner, 1902).

26 G H Mead, Mind, Self and Society from the Standpoint of a Social Behaviorist (Chicago: University of Chicago Press, 1934), p. 68. 
appreciate why libellous publications might impact upon an individual's sense of selfesteem; how defamatory statements can impact upon our capacity to engage in society. Over time, and drawing on the concepts of human dignity and autonomy, Strasbourg jurisprudence has expanded the coverage of Article 8 to encompass both a person's physical and their psychological integrity. ${ }^{27}$ In light of this, it is perfectly reasonable to contemplate a Convention right to reputation. It is also easy to understand why libel law should correct for harms to self-esteem caused by false statements.

In terms of the level of compensation that might be necessary to address harms of this type, it is important to appreciate that the level of esteem in which we think others hold us is not the singular determinant of self-worth. Often, perhaps usually, the influence of reflected appraisals will be trifling relative to other factors. Hence, in standard cases the appropriate measure of damages might be expected to be quite low. On occasion, however, the psychological impact of perceived reputational harm may be devastating. Most poignantly, in the libel case involving Christopher Lillie and Dawn Reed (two nursery-school workers wrongly accused of systematically sexually abusing children in their care), $\mathrm{Mr}$ Justice Eady commented that:

with the possible exception of murder, it is difficult to think of any charge more calculated to lead to the revulsion and condemnation of a person's fellow citizens than that of the systematic and sadistic abuse of children ... [the defendants] must have appreciated too that the claimants' lives would never be the same again. It would not have taken much imagination to visualise the virulence of the reactions they would stir up in the general public. The two claimants recalled in evidence how they had to leave in haste their homes, families and career prospects. They had to go into hiding. ${ }^{28}$

Asked during cross-examination how she had felt in the months following publication of the allegations, Reed explained "low enough to think my family would have an easier life without me... I would sit at the top of Marsden cliffs in my car with the engine running". ${ }^{29}$ For such very significant harms, the libel regime should provide access to very substantial compensatory damages.

27 See, for example, Von Hannover v Germany (2005) 40 EHRR 1, at [33]; Karako v Hungary (2011) 52 EHRR 36; A v Norway 28070/06 [2009] ECHR 580 (9 April 2009); Polanco Torres and Movilla Polanco v Spain 34147/06 (unreported 21 September 2009). It was contested in Karako itself, however, in a partly concurring judgment delivered by Judge Jociene who considered that the prior caselaw had been consistent in finding reputation always to fall within Article 8. In R (Gillan) v Commissioner of Police for the Metropolis [2006] UKHL 12, Lord Bingham noted that "'private life' has been generously construed to embrace wide rights to personal autonomy" (at [28]).

28 Lillie and Reed v Newcastle City Council [2002] EWHC 1600 (QB), at [1538]-[9].

29 B Woffinden and R Webster, "Cleared", The Guardian, 31 July 2002. A similar illustration can be seen in the admission by Professor Phil Jones of the University of East Anglia Climate Research Unit that he had contemplated suicide following allegations that he had manipulated research data concerning the impact of human behaviour on the global climate. Professor Jones was subsequently exonerated of wrongdoing - see A Laing, "Climategate' Professor Phil Jones 'considered suicide over email scandal"', Daily Telegraph, 7 February 2012. 


\section{TAKING ACCESS TO JUSTICE SERIOUSLY}

Access to justice is important in terms of both principle and practice. ${ }^{30}$ In terms of principle, there is a clear association between such access and the rule of law. It is not impossible to imagine a disgruntled claimant, too poor to go to the law, somehow taking the law into their own hands. ${ }^{31}$ It is also possible to understand the curiously one-sided representation of the problems of libel law in the national press as a specific response to frustration of some defendants in the face of what they perceive as obvious, but intractable, injustice.

On the practical side, the chilling effect of the very high potential liability in costs for defendants under the current libel regime has rightly been a primary focus of the libel reform debate. Estimates vary, but it is not uncommon for it to be suggested that contested actions will likely result in costs bills that run into the millions of pounds. ${ }^{32}$ As a matter of logic, the upshot is likely to be that there will be financial incentives to settle cases irrespective of the merits of the claim. For even well-heeled defendants, the potential cost of defending a libel action may sometimes be prohibitive.

The main factors that are said to contribute to the cost of proceedings are the protracted nature of libel proceedings, and the high base costs charged by specialist libel lawyers. In addition, where utilised, conditional fee agreements (CFAs) currently permit the charging of an uplift on costs (the "success fee") of up to 100 per cent (although in practice this uplift would rarely exceed a figure of half that and figures produced by claimant law firms, to which we have had access, suggest that the average uplift is around 20 per cent). Moreover, "after-the-event" (ATE) insurance premiums that protect the users of CFAs against the risk of incurring the costs burden associated with losing the case can also be charged to the losing party.

While the practical difficulty for libel defendants in securing access to justice is muchdiscussed, the converse problems facing claimants are rarely highlighted. The cost of libel actions is prohibitive for many prospective claimants. Indeed, the one-time "rule of thumb" regarding assessment of the legal risk of publication rested upon the claimant's means. This calculus has been altered somewhat by the availability of CFAs. That said, CFAs and hence the courts more generally are not available to all prospective claimants, but rather only to those who satisfy the risk management regimes operated by claimant lawyers. Proposals -

30 See, for example, Lord Neuberger MR, "Has mediation had its day?", First Gordon Slynn Memorial Lecture (2010): "the law's majestic equality is for civil justice of fundamental importance. Notwithstanding the views of Anatole France to the contrary, equal access to justice for all underpins our commitment to the rule of law. It ensures that we live not under what Friedrich Meinecke characterised as a 'government of will [but under] a government of law.' It ensures that any one individual citizen can come before the courts and stand before the seat of justice as an equal to his or her opponent - whether that opponent is another such individual, a powerful corporation or the state itself. We should not, in light of this, be too surprised to note that equality before the law, isonomia - of which equal access to the courts is one aspect - was for the citizens of Athens two and a half thousand years ago, the basis out of which democracy arose."

31 A demonstration of this point provides the dénouement of Heinrich Böll's classic novel The Lost Honour of Katharina Blum (London: Vintage Classics 1993).

32 An oft-cited statistic is that costs of proceedings here are four times as high as the next most expensive European state (Ireland), and 140 times the average cost in other European jurisdictions - see Programme in Comparative Media Law and Policy, Comparative Study of Costs of Defamation Proceedings Across Europe (2008), available at http://pcmlp.socleg.ox.ac.uk/ (accessed October 2010). The sustainability of this research finding has, however, been persuasively challenged - see D Howarth, "The cost of libel actions: a sceptical note" (2011) 70 Cambridge Law Journal 397-419. 
such as that floated by the last government ${ }^{33}$ or that put forward by Lord Justice Jackson ${ }^{34}$ and now presented to Parliament with some variation by the current government ${ }^{35}-$ to amend the current regime by drastically reducing the available success fees risk exacerbating these concerns. Having conducted a review of the available evidence on the cost of libel proceedings, one commentator concluded that "the reality is that we know little about the costs of libel cases, and what we do know does not justify precipitate measures that would have the effect of reducing claimants' access to justice". 36

\section{Application: the purposes of libel law}

In determining the purposes of libel law, a reasonable starting point is to note what are the stated objectives of various remedies currently afforded to successful claimants. In English law, damages are the standard remedy, and four objectives underpinning their award can be discerned: to compensate for distress, hurt and humiliation; to compensate for unquantifiable, presumed reputational harm; to compensate for actual (provable) harm; and to vindicate or restore the claimant's damaged reputation. ${ }^{37}$ In the paragraphs that follow we note how these objectives might best be understood in light of the foregoing discussion, and highlight the ramifications of our analysis for the design of a coherent libel regime. This involves parsing out the different forms of damage that may be caused by a libel, and hence the range of purposes to be served by a coherent libel law and the remedies that it might afford.

\section{Compensating ARTicle 8 harm}

As regards the objective of compensating for the distress and injury to feelings caused by libel, it would seem reasonable to assert that the harm that requires compensation in this regard is that identified in the foregoing discussion of the social psychology of reputation. That is, the loss of dignity or self-esteem occasioned when an individual believes that others have been caused - wrongly - to think less of him or her. It is to the extent of such harm

33 The abortive Conditional Fee Agreements (Amendment) Order 2010 proposed under s. 58(4) of the Courts and Legal Services Act 1990 was criticised by the House of Lords Merits Committee (HL 94), the House of Commons First Delegated Legislation Committee (30 March 2010) and in debate on the floor of the House of Lords (HL Debs, vol. 718 cols 1152-78) before being lost in the "wash-up" before the prorogation of Parliament prior to the 2010 general election. In evidence to the Lords committee, law firm Carter Ruck noted "widespread concern within the legal profession that the proposed reduction in success fees would seriously reduce - if not eliminate altogether - the rights of ordinary individuals without substantial means to obtain access to justice in defamation and privacy cases". Professor Richard Moorhead of Cardiff University concurred: "the basic economics of conditional fee agreements would suggest that . . a level of $10 \%$ uplift would prevent all but the most meritorious cases from proceeding on a conditional fee. For rich litigants, this presents no problem, for poorer litigants this presents a major impediment to access to justice." R Jackson, Review of Civil Litigation Costs (London: Ministry of Justice 2010), ch. 32.

35 Under Part 2 of the Legal Aid, Sentencing and Punishment of Offenders Bill 2011, "success fees" and "after the event" insurance will no longer be recoverable from the losing party. A lawyer will still be able to recover a success fee from a client under a CFA, but how it is to be calculated in certain proceedings will be subject to further regulation. In defamation cases, the government has proposed that the maximum success fee will remain at $100 \%$ and that this will be paid from the damages recovered (damages for non-pecuniary loss in all tort claims - which includes defamation - will be increased by $10 \%$ ). See, http://inforrm.wordpress.com/ 2011/03/29/news-conditional-fees-the-government-responds-to-the-consultation/. As the mean average award of damages in a defamation claim is around $£, 38,000$ and the median award around $f 20,000$ (for the raw data used to calculate this figure, see C Doley and A Mullis (eds), Carter-Ruck on Libel and Privacy 6th edn (London: LexisNexis 2010), appendix on awards of damages in defamation claims), the practical effect of implementation of the government's proposals is likely to be a significant reduction in the ability of claimants to secure access to justice.

36 Howarth, "The cost of libel actions", n. 32 above.

37 John v MGN Ltd [1997] QB 586, at 607 (per Sir Thomas Bingham MR). 
that we consider the protection of reputation to fall within the ambit of Article 8 of the Convention. Actual harms to reputation speak more to the conception of reputation as property. ${ }^{38}$ Understanding this head of damages in line with the above discussion entails a number of ramifications for the design of the libel regime.

\section{(a) Ramifications: meaning}

Disputes about meaning are often central to libel actions: "very often if not always the most important issue is meaning". 39 The result is that much lawyers' time and hence significant legal costs are spent on the matter. This situation arises in part because the law requires a "single meaning" to be inferred from the impugned publication, ${ }^{40}$ and the determination of this single meaning is usually left to the jury or judge at the end of the trial. Thus, argument must sometimes be presented to the court - by both parties to the action - relating to meanings that are ultimately deemed irrelevant. If one understands this element of the harm in question as having been caused in the mind of the claimant, then it is the claimant's inferred meaning that should provide the basis for the subsequent consideration, subject to a test of reasonableness. The reasonableness threshold would introduce a necessary element of objectivity into the exercise. Such a test would speak to the need for a sufficient level of seriousness as is required to engage Article 8 ECHR. ${ }^{41}$ Hence, the determination of meaning becomes very straightforward. The question is not "What is the meaning?", but rather only "Is the given meaning a reasonable one?"

The ramifications of this approach are very significant. There would be no reason to leave the determination of meaning to a jury. Hence, there would be no reason to persist with the "single meaning rule", a legal fiction - it is obvious that in fact words are understood in different ways by different people - that has been described as "anomalous, frequently otiose and, where not otiose, unjust". ${ }^{42}$ There would be no need to argue

38 See Post, "The social foundations", n. 24 above. We do not here assert that damages should not be recoverable for provable financial loss, but instead intend to make the point that where the only harm caused by a defamatory statement is financial, Article 8 is not engaged.

39 Uncorrected evidence given by Mr Justice Tugendhat to the Joint Committee on the Draft Defamation Bill, 7 July 2011, at Q40. For an illuminating discussion of, inter alia, the law and practice regarding the determination of meaning in English and Australian defamation law, see A Kenyon, Defamation Law: Comparative law and practice (London: UCL Press 2006). This research, based on qualitative interviews undertaken in 2000 - and followed up in 2003 - with a sizeable cross-section of libel practitioners, gives substantial insight into how libel claims are pleaded that is available from few other sources. See also, Doley and Mullis, Carter-Ruck, n. 35 above, Pt 3 "Practice and procedure".

40 The single meaning rule requires the court to select one meaning from the range of those that the publication may reasonably be capable of bearing as that which would be discerned by a hypothetical ordinary, reasonable reader. The House of Lords affirmed this rule in Charleston v News Group Newspapers [1995] 2 AC 65.

41 In Wood v Commissioner of Police for the Metropolis [2009] EWCA Civ 414, Laws LJ commented that the "core right protected by Article 8, however protean, should not be read so widely that its claims become unreal and unreasonable ... the alleged threat or assault to the individual's personal autonomy must (if Article 8 is to be engaged) attain 'a certain level of seriousness"' at [22]-[23]. See also R (Gillan) v Commissioner of Police for the Metropolis [2006] UKHL 12, at [28] (per Lord Bingham); Secretary of State for Work and Pensions v M [2006] UKHL 11, at [83] (per Lord Walker).

42 Ajinomoto Sweeteners Europe SAS v ASDA Stores Ltd [2010] EWCA Civ 609 at [31] (per Sedley LJ). Lord Justice Rimer added that "if the single meaning rule does achieve a fair balance in defamation law between the parties' competing interests, that would appear to be the result of luck rather than judgment ... the application of the rule can also be said to carry with it the potential for swinging the balance unfairly against one party of the other, resulting in no compensation in cases when fairness might suggest that some should be due, or in overcompensation in others" at [43]. 
defences relevant to multiple, indeterminate meanings. ${ }^{43}$ Indeed, the defendant would know from the first contact with the prospective claimant what meanings required defending. $\mathrm{He}$ or she could then choose whether to argue that the proposed meaning was an extravagant - and hence unreasonable - inference to draw from the published words, to rely on justification, fair comment or privilege, or to accept the claimant's interpretation of the impugned words as reasonably possible and to offer some suitable remedy. Especially given the approach to remedies - discussed below - entailed by the Article 8 starting point, the likelihood would be that in the many cases where what has upset the claimant was not in fact what the defendant intended to convey, the immediate clarity on meaning would allow speedy redress without any need to revert to court. The existing incentive for defendants to introduce obfuscatory alternative meanings more suited to their own legal arguments would be substantially reduced. The claimant would have an incentive to plead mainstream or natural meanings so as to satisfy the reasonableness test.

\section{(b) Ramifications: whether a statement is defamatory}

The fact that a given meaning is accepted by the court as reasonable, does not automatically entail that it must also be considered to be defamatory. This requires a separate assessment. Under the current law, the standard test is that of whether the words have a tendency to lower the claimant in the estimation of right-thinking people generally. ${ }^{44}$ This has recently been restated by Tugendhat J following a review of numerous previous definitions: "a publication is defamatory of a claimant if it substantially affects in an adverse manner the attitude of other people towards him, or has a tendency so to do". 45 Clearly, the claimant will believe that the pleaded meaning is defamatory as this subjective perception is what is alleged to have generated the harm complained of. As with the determination of meaning, however, the court should not simply accept the claimant's contention. If the impugned words cannot be fairly read as defamatory, then the Article 8 harm is caused not by the words published, but rather by some over-sensitivity or paranoia on the part of the claimant. Whether in fact imputations are defamatory should remain an objective question.

A useful parallel can be seen in the way in which workplace harassment on grounds of age, religion, sexual orientation, or other "relevant protected characteristic" is considered under the Equality Act 2010.46 Section 26(1) provides that harassment occurs where a person engages in unwanted conduct, and that conduct has the purpose or effect of violating the victim's dignity, or creating an intimidating, hostile, degrading, humiliating or offensive environment for the victim. In determining whether the second part of this test is satisfied, that is whether the conduct in question has one or other of the deleterious effects, the Employment Tribunal will consider the victim's perception, the other circumstances of the case, and whether it is reasonable for the conduct to be understood as

43 As Andrew Kenyon has explained: “a major reason lawyers differ about meaning may not be any complexity with meaning per se. At least within defamation law, the test for meaning is simple, and refers to ordinary understandings, so important theoretical questions are bracketed out and play no explicit role in defamation doctrine. Instead, lawyers may differ about meaning because of their concern with justification. Claimants seek to plead a short, sharp and memorable meaning that cannot be proved true - which may not be the most plausible meaning to arise from the publication. And defendants seek to plead a similar but broader and less damaging meaning that will allow them to adduce damaging evidence they have about the claimant" - see Kenyon, Defamation, n. 39 above, p. 120.

44 Sim v Stretch [1936] 2 All ER 1237, at 1250 (per Lord Atkin). For recent discussions of the concept of defamatory meaning, see L McNamara, Reputation and Defamation (Oxford: OUP 2007), especially Pt 3; Doley and Mullis, Carter-Ruck, n. 35 above, pp. 59-77.

45 Thornton v Telegraph Media Group Ltd [2010] EWHC 1414 (QB).

46 The full listing of relevant protected characteristics is set out in s. 26(5). 
having that effect. ${ }^{47}$ Explaining this provision in Richmond Pharmacology $\mathrm{v}$ Dhaliwal, Underhill J noted that:

a respondent should not be held liable merely because his conduct has had the effect of producing a proscribed consequence: it should be reasonable that that consequence has occurred ... proscribed consequences are, of their nature, concerned with the feelings of the putative victim: that is, the victim must have felt, or perceived, her dignity to have been violated or an adverse environment to have been created. That can, if you like, be described as introducing a "subjective" element; but overall the criterion is objective because what the tribunal is required to consider is whether, if the claimant has experienced those feelings or perceptions, it was reasonable for her to do so ... if, for example, the tribunal believes that the claimant was unreasonably prone to take offence, then, even if she did genuinely feel her dignity to have been violated, there will have been no harassment within the meaning of the section. Whether it was reasonable for a claimant to have felt her dignity to have been violated is quintessentially a matter for the factual assessment of the tribunal ... dignity is not necessarily violated by things said or done which are trivial or transitory ... it is ... important not to encourage a culture of hypersensitivity or the imposition of legal liability in respect of every unfortunate phrase. ${ }^{48}$

The view of a claimant on whether an imputation was defamatory should be relevant to but not determinative of the view reached in libel adjudications.

\section{(c) Ramifications: defences}

The primary defences that would be necessary in the context of the revised approach to compensation for Article 8 harm would be those focused on meaning: justification (truth) and honest comment (honest opinion). There would be no particular need to retain the Reynolds privilege, unless the possible quantum of damages is very significant. That defence was introduced to offset the chilling effect of the high costs and potential liability in damages of libel actions, and thereby to encourage publishers to communicate information that they believed to be true and in the public interest. ${ }^{49}$ Given the approach to meaning outlined above, the complexity and hence cost of the majority of such actions should be very significantly reduced. It would be faintly comical - and obviously tautological - for defendants to claim that costs remain a significant problem necessitating the retention of a public interest defence to limit the chilling effect of libel, if the primary generator of costs was precisely the defendant's own choice to rely on that public interest defence. Hence, if damages too are limited, then the logic for the defence dissolves. This is especially the case when one considers that there have always been concerns regarding the pathological consequences of the defence. One complaint regarding Reynolds - and the US comparator approach in New York Times $\mathrm{v}$ Sullivan - is that it displaces all focus away from the truth or otherwise of the allegations made onto the question of whether journalistic practices have been responsible. ${ }^{50}$ Moreover, claimants do not receive

47 S. 6(4).

48 [2009] IRLR 336, at [15] and [22]. In that case, the tribunal was in fact interpreting a very similar predecessor provision to s. 26.

49 There is some debate as to whether the Reynolds defence was intended by the House of Lords to permit the publication of information that the publisher believed to be true, but was aware at the time of publication that it would not be possible to prove so to the satisfaction of the court. An example may be where a source of information was always unwilling to defend an allegation.

50 See, for example, the contribution of Professor Roy Greenslade to the "Reframing Libel" symposium, n. 12 above. 
vindication, and inaccuracies that misinform the wider public are not corrected. This argument suggests that some form of two-track libel regime, with different routes for standard and more serious cases, may be appropriate.

\section{(d) Ramifications: measure of damages}

If a meaning complained of proves to be both reasonable and defamatory and no defence is made out, then two questions regarding damages arise. First, what should be the possible range of damages awards and, second, how should the measurement of damages in any given case proceed. It could not be appropriate simply to invite the claimant to depict the harm suffered and to match the damages award to the poignancy of this narrative. The administration of justice should not seek to mimic a drama school audition. That said, there should be some attempt to match the damages award with the subjective assessment of the harm actually suffered. It should not be an exclusively objective determination. This is not a straightforward exercise:

It is self evident that the assessment of compensation for an injury or loss which is neither physical nor financial presents special problems for the judicial process, which aims to produce results objectively justified by evidence, reason and precedent. Subjective feelings of upset, frustration, worry, anxiety, mental distress, fear, grief, anguish, humiliation, unhappiness, stress, depression and so on and the degree of their intensity are incapable of objective proof or of measurement in monetary terms. Translating hurt feelings into hard currency is bound to be an artificial exercise ... there is no medium of exchange or market for non-pecuniary losses and their monetary evaluation ... hurt feelings are none the less real in human terms. The courts and tribunals have to do the best they can on the available material to make a sensible assessment, accepting that it is impossible to justify or explain a particular sum with the same kind of solid evidential foundation and persuasive practical reasoning available in the calculation of financial loss or compensation for bodily injury. 51

Libel law, of course, is not the only context in which such estimations must be made. Here also, for example, a useful parallel can be drawn from the context of employment discrimination cases in which damages for injury to feelings, as distinct from psychiatric injury, have been considered by the Court of Appeal.

In respect of the range of possible damages award, in the overwhelming majority of libel cases the quantum of damages that would be necessary to compensate for the Article 8 harm suffered by a claimant would likely be relatively low. In that context, it is reasonable to consider a damages "cap". A figure of $£, 10,000$ has been mooted by some. 52 A "hard" cap on libel damages, however, would be inappropriate. A similar view informed the Court of Appeal when determining damages for injury to feelings in the context of employment law. In Vento v Chief Constable of West Yorkshire Police, Mummery LJ suggested three bands

51 Vento v Chief Constable of West Yorkshire Police [2002] EWCA Civ 1871, at [50]-[51] (per Mummery LJ).

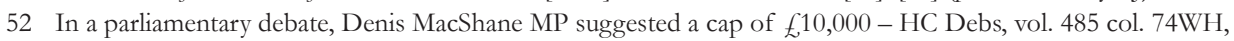
17 December 2008. Moreover, the Index/PEN report, n. 1 above, also suggested a cap of $£_{1} 10,000$, but with room for additional sums where special damage can be proven (the report also emphasised the preferability of some form of apology remedy) - see n. 2 above. We have previously stated, however, that "this level of damages cap is seriously flawed" on the basis - inter alia - that such an award would simply be insufficient to compensate someone in the position of the McCanns or Lillie and Reed (nursery workers accused of child sexual abuse in a public authority report) - see Mullis and Scott, "Something rotten", n. 5 above, pp. 177-8. We note also that in a recent public lecture, Lord Hoffmann contrasted the proposed cap with the exorbitant sums that newspapers regularly pay sources for salacious stories - see "Lord Hoffmann and libel tourism: three comments", Inforrm, 5 March 2012. No proposal to cap damages was included in the Lester Bill. 
of compensatory award. ${ }^{53}$ An award within the lowest band - between $f, 500$ and $f, 6000-$ would be appropriate for "less serious cases", while awards in the middle band - between f,6000 and $f, 18,000$ - should be made in "serious cases". Awards in the highest band, stretching to $f, 30,000$, were considered appropriate "in the most serious cases, such as where there has been a lengthy campaign of discriminatory harassment on the ground of sex or race". The court accepted that there could be circumstances that warranted compensation above the rate envisaged in the highest of these bands, but expected that this would occur "only in the most exceptional case". ${ }^{54}$ Compensation for Article 8 harm caused by libel would normally be adequately addressed by an award falling within the first or second of these bands, and occasionally the third. Very exceptionally, as perhaps with the situation caused by the libel in Lillie and Reed, it should be possible for courts to make more significant awards in order to achieve justice in light of the degree of harm caused to a claimant's psychological integrity.

As regards the determination of an award of damages in any given case, the court can be expected to allocate the case to the appropriate banding of the harm caused and to reach a just award within the banding. In Vento, the court admitted of "considerable flexibility, allowing tribunals to fix what is considered to be fair, reasonable and just compensation in the particular circumstances of the case". 55 As one element of this exercise, a court can realistically be asked to countenance the claimant's own evidence on the psychological impact of a libel. The subjective evidence would then stand as one of a range of factors in its determination of an appropriate damages award. ${ }^{56}$

\section{(e) Ramifications: standing of corporations}

One significant debate regarding libel reform concerns the question of whether corporations should continue to be permitted to sue in libel, and if so whether they should be subjected to especial requirements such as an obligation to prove damage. ${ }^{57}$ The current position with regard to damages is that corporations cannot sue in respect of injury to feelings, ${ }^{58}$ but they can recover substantial damages even in the absence of proof of special damage for words that have a tendency to injure them in the way of their business. ${ }^{59}$ Under the revised understanding of injury to feelings described above, there would remain no basis for corporations to recover for Article 8 harm. ${ }^{60}$

\section{(f) Ramifications: costs and access to justice}

The changes outlined above on the determination of meaning and on defences would entail that there would be a very substantial reduction in costs in respect of Article 8 harm. The upshot would be that there would be enhanced access to justice for relatively impecunious

53 [2002] EWCA Civ 1871, at [65]. The band-limits set out in Vento were in fact slightly lower than those set out in the text that follows. They were adjusted for inflation by the Employment Appeal Tribunal in Da'Bell v National Society for the Prevention of Cruelty to Children (NSPCC) [2010] IRLR 19, at [44]-[5].

54 Vento, n. 53 above, at [65].

55 Ibid. at [66].

56 The importance of the subjective narrative in decisions on the award of damages was explicitly recognised by the Employment Appeal Tribunal in Da'Bell, see n. 53 above, at [47].

57 The Index/PEN report recommended that corporations should be denied standing to sue in libel, and be required instead to rely upon malicious falsehood - see n. 1 above. Cl. 11 of the Lester Bill provides that corporations should have to prove "substantial financial loss".

58 Lewis v Daily Telegraph [1964] AC 234 at [262] (per Lord Reid).

59 Jameel v Wall Street Journal Europe SPRL [2006] UKHL 44.

60 The position with regard to other forms of damage is considered further below. 
claimants who are not currently able to avail of a CFA, while the chilling effect on publication would be significantly reduced.

\section{VINDICATING REPUTATIONS AND COMPENSATING FOR INTANGIBLE HARM}

In addition to compensating the claimant for hurt feelings, damages are also currently awarded both to compensate for unquantifiable, presumed reputational harm and to vindicate/restore the claimant's reputation. These heads of damage are available in order that the harm that is caused to the claimant's reputation in the minds of third parties is corrected and compensated. We are not persuaded that in either respect the current form of remedy allowed is the most efficacious or appropriate available.

\section{(a) Discursive remedies for vindication}

The award of damages to vindicate the claimant's reputation was justified by Lord Hailsham in Cassell v Broome as necessary "in case the libel, driven underground, emerges from its lurking place at some future date ... [to allow the claimant] to point to a sum awarded by a jury sufficient to convince a bystander of the baselessness of the charge". 61 Of course, money can be used to serve such a function, but we are not persuaded that it represents the best means of achieving vindication. In other jurisdictions, this function is fulfilled by the provision of a discursive remedy. As Hugh Tomlinson QC has pointed out, "in many European countries the primary remedy is an order for the publication of corrections or apology - often in the form of the publication of a summary of the Court's judgment. This would provide vindication without the need for substantial damages." 62 An alternative would be a mandated declaration of falsity or a right of reply published with due prominence. Such a remedy has been said to be unavailable at common law, ${ }^{63}$ though it does exist under s. 9 of the Defamation Act 1996 on the summary disposal of a claim under s. 8 of the Act. 64

The most effective way of vindicating a person's reputation would be to ensure that the truth is aired, and misrepresentations corrected. This would require new provision for the award of an appropriate discursive remedy. This view was presaged, in part, in the Index/PEN report: "the chief remedy in libel should be an apology, not financial reward". 65 The grant of a discursive remedy would remove the need to award damages to vindicate the claimant's reputation, but would instead provide the claimant with the very thing that most claimants want: a public declaration that they did not do what they were alleged to have done. ${ }^{66}$ The chilling effect of a potentially large damages award would be reduced, and importantly - if one is serious about achieving one of the underlying purposes

61 [1972] AC 1027, at 1071.

62 "Libel, damages and declarations of falsity", Inforrm, 2 November 2011. See, generally, G Bruggemeier, A Ciacchi and P O'Callaghan (eds), Personality Rights in European Tort Law (Cambridge: CUP 2010); H Koziol and K Warzilek (eds), The Protection of Personality Rights Against Invasions by Mass Media (New York: Springer Wein 2005).

63 Loutchansky v Times Newspapers (No 6) [2002] EMLR 44.

64 Pursuant to Defamation Act 1996, s. 9(1), the claimant may obtain such of the following as may be appropriate: (a) a declaration that the statement of which he or she complains was false and defamatory; (b) an order that the defendant publish or cause to be published a suitable correction and apology; (c) damages not exceeding $£ 10,000$; and (d) an order restraining the defendant from publishing or further publishing the matter complained of.

65 Index/Pen report, n. 1 above, p. 8.

66 This general preference among libel claimants for a discursive remedy is recognised in the Pre-Action Protocol for Defamation, para. 1.4, available at www.justice.gov.uk/guidance/courts-and-tribunals/courts/procedurerules/civil/contents/protocols/prot_def.htm (accessed July 2011). 
of freedom of expression - then a closer approximation to the truth would enter the public sphere and be made available to the public. As the Press Complaints Commission (PCC) Editors' Code of Practice states, “a significant inaccuracy, misleading statement or distortion once recognized must be corrected, promptly and with due prominence, and - where appropriate - an apology published".67 Therefore, we propose the withdrawal of damages for vindication to be replaced by an appropriately designed scheme of discursive remedies.

Quite what such an appropriate scheme of discursive remedies might comprise is open for debate. Clearly, where error has occurred correction should follow. On occasion, this may amount to the total retraction of a piece. How such corrections should be made will depend on the form that the original publication has taken. With ongoing online publication, for example, amendment could easily be made to the article itself so that future readers would not be misled. It would seem to be best practice, however, for such changes also to be accompanied by a note at the beginning or end of the piece indicating that such a revision had been made. For hard copy publication, it would seem appropriate for any correction or retraction to be highlighted in a dedicated part of the publication or by some other placement that would secure due prominence. ${ }^{68}$ There may also be a role for rights of reply. It would seem to go too far, however, to insist that a correction or retraction must normally be accompanied by an apology. ${ }^{69}$ Nevertheless, it may be reasonable for the libel regime to mandate apologies or to award declarations of falsity in cases where the claimant assumes the burden of proof and demonstrates the falsity of statements made to the satisfaction of the adjudicator.

\section{(b) Withdrawal of the remedy in damages for intangible harm}

In addition to the withdrawal of damages for vindication, we suggest that no award should be made for unquantifiable, presumed harm to reputation. In some respects, this may appear to conflict with the concern regarding the social impact that a defamatory statement can have on a person. We do not underestimate the harm that such a statement can cause to a person's standing in his or her community, and indeed social psychological research is beginning to evidence the fact that in many cases reputational damage is likely to linger even after the truth is published. Discursive remedies designed to restore reputation will sometimes not be perfect in effect; they may not entirely eradicate the "stain" on the claimant's reputation. In the face of such arguments, the reasons for recommending that damages for unquantifiable, presumed harm to reputation be withdrawn are largely pragmatic. The award of damages under Article 8 ECHR for the pain and humiliation caused by the publication together with an appropriate discursive remedy for vindication will provide an adequate - although admittedly not perfect - remedy for the harm caused. The proposed remedies would give most claimants what they want. They avoid the indeterminacy surrounding the task of fixing on an appropriate sum, and they reflect the underlying importance of freedom of expression.

\section{(c) Ramifications: determination of meaning for purposes of the discursive remedy}

If a new discursive remedy is introduced and damages for vindication and presumed reputational harm are withdrawn, a question arises as to whether it is still appropriate to use the meaning pleaded by the claimant and determined by the judge to be a reasonable one. In other words, if the judge orders the defendant to provide a discursive remedy, in respect

67 Cl. 1(ii).

68 It does not seem vital to us that efforts to achieve "due prominence" should necessarily entail that corrections should be placed on the same page with the same space dedicated as the original, offending publication.

69 See further, Draft Defamation Bill, see n. 3 above, Q604 (per Desmond Browne QC and Hugh Tomlinson QC). 
of what meaning should the libel be assessed and any redress made? It is arguable that the continued use of the claimant's meaning(s) remains entirely appropriate. Put another way, all defamatory meanings pleaded by the claimant should, if deemed reasonable by the adjudicator, be met with a discursive remedy. Where it is determined that the meaning(s) pleaded by the claimant is in fact a reasonable one, then in effect this entails that some reasonable readers would have read the words in the way set out. Given this, where no defence is made out, it seems entirely appropriate to require the defendant either to correct the complained of statement and/or to explain that the impugned meaning was unintended. In either event, the current single meaning rule could be safely abandoned here as in the claim for malicious falsehood. ${ }^{70}$

\section{(d) Ramifications: corporations, standing and appropriate remedies}

As is implicit in the foregoing, we take the view that - in the absence of proof of special damage - corporations should be entitled only to a discursive remedy, and they should be unable to recover damages for unquantifiable, presumed reputational harm. We have previously noted the importance of the corporate sector to the British economy, ${ }^{71}$ and we view with concern the approach taken in the Lester Bill that would only allow a company to sue if it can prove that the publication of the words or matters complained of has caused or is likely to cause "substantial financial loss". ${ }^{72}$ We also recognize the real danger, however, that large and powerful companies may, through the threat of a libel claim, chill legitimate and accurate comment about their conduct. Rather than isolating corporations and specifically limiting their right to sue in any respect, our proposals address incidentally the potential misuse of libel by all relatively powerful entities to achieve strategic goals unrelated to the substantive merit of claims.

\section{(e) Ramifications: defences}

So far as defences are concerned, under our approach the defendant would be free to rely on the defences of justification (truth) and honest comment (honest opinion). We see no immediate reason to make significant changes to these defences as they currently exist in English law. ${ }^{73}$ Insofar as justification is concerned, the defence would succeed only if the defendant could prove the words true in the meaning(s) pleaded by the claimant and accepted by the judge as a reasonable meaning.

As regards Reynolds privilege, we would draw a distinction between standard cases and those involving more serious and/or damaging statements. Where only a discursive remedy and (possibly) a minimal measure of damages for Article 8 harm are sought, the prepublication umbrella afforded by Reynolds against the potential chilling effect of the threat of a libel claim is unnecessary. The chilling effect will have been significantly addressed by simplifying the existing procedure, reducing costs and limiting the remedies available. To

70 Ajinomoto Sweeteners Europe SAS v ASDA Stores Ltd [2010] EWCA Civ 609.

71 Mullis and Scott, "Something rotten", n. 5 above.

72 Defamation Bill 2010, cl. 11. The government opened the question for consultation in Draft Defamation Bill Consultation, Cm 8020, March 2011, available at: www.justice.gov.uk/consultations/draft-defamation-bill.htm, at paras 135-46. The Joint Committee Report on the Draft Defamation Bill (www.parliament.uk/business/ committees/committees-a-z/joint-select/draft-defamation-bill1/news/publication-report/) recommends that the government should go further than the Lester Bill and, in addition to requiring a company to prove that there is a likelihood of actual financial loss, should require corporations to obtain the permission of the court before bringing a libel claim (para. 116).

73 This is not to contend that there is no room for a considered review of the fair comment defence to be undertaken to ensure that its various components are apposite given the function that the defence is understood to perform within the wider corpus of libel law. 
allow a defendant to rely on Reynolds in this situation would unduly weight the balance in favour of the defendant and would unnecessarily increase the costs in such cases. ${ }^{74}$

Again, however, there is an argument for a bifurcated approach dependent upon the severity of Article $8 \mathrm{harm}$ and/or the capacity to plead special damage. In the latter type of case, there is very much more at stake. The potential costs of defending a full-blown libel claim where the allegation made is of a particularly serious nature or has particularly serious repercussions, in addition to the extent of the damages that may be awarded, inevitably means that the chilling effect would be considerably increased. In these circumstances, it seems appropriate to allow the defendant to avail itself of Reynolds if sued. The knowledge that such a defence is available would limit the potential prepublication chilling effect. If at trial the defendant sought but failed to rely on justification or simply relied solely on Reynolds by way of defence, however, the claimant should be entitled to a declaration of falsity or at least a right of reply. This would properly value both the Article 10 and Article 8 rights at stake.

\section{(f) Reflections}

Clearly there are downsides for both parties in these proposals. So far as the defendant is concerned, it could be forced to provide a proper and prominent correction or have a declaration of falsity issued against it that would be placed on the record, and could be relied upon by the claimant to vindicate reputation. Yet the media, and newspapers in particular, have traditionally been very hostile to the imposition of a mandated apology or declaration of falsity. As the eminent claimant lawyer Keith Schilling has noted, "newspapers want to pay negligible damages and print a small apology buried away in the middle of the paper - this of course achieves nothing except to annoy the person injured". ${ }^{75}$ Mandating a discursive remedy would certainly involve interference with the defendant's Article 10 right "not to speak". We consider, however, that this would not be disproportionate, especially in light of the countervailing interest of the wider public in being fully and accurately informed on matters of public concern. An obligation to dedicate space to discursive remedies would be commercially disadvantageous: no recognized defendant that relies for its revenue on a reputation for accuracy, probity and credibility wants to highlight publicly that it has gotten facts wrong. The upside for media defendants would be that the public and swift acceptance of error would have the useful, and entirely desirable, impact of enhancing journalistic credibility.

Perhaps most importantly, the award of a discursive remedy offers substantial benefits for society as a whole. Where granted, they would have the important effect that the public is not left misinformed by inaccurate but uncorrected statements on matters of public importance. Today, where Reynolds is successfully relied upon, in the absence of a voluntary publication of a correction by the defendant, the potential exists for an untrue statement to remain on the public record. Moreover, even where a plea of justification fails and the claimant is awarded damages, the mere existence of a reasoned judgment in favour of the claimant only doubtfully has the symbolic power of a straightforward and short statement of correction or an apology. The award of a discursive remedy would avoid these

74 It can be noted further that under this scheme the publication on the given matter of public interest could be entered into the public domain, and then any subsequent correction or retraction could be explicit that the discursive remedy was being afforded only because the truth of the statement could not be proven to the satisfaction of the court. Should the claimant wish to press the matter and seek an apology or declaration of falsity, he or she might reasonably be asked to assume the burden of proving falsity. 
unsatisfactory results, and properly validate the claimant's Article 8 rights while ensuring that the public as a whole was aware of the errors in the original publication.

So far as the claimant is concerned, it must be recognized that the award of damages only for the pain and humiliation caused by the defamatory statement together with a discursive remedy may not wholly compensate the claimant for the injury he or she has suffered. Even after the publication of a correction and payment of a sum of damages, the fact is that in many cases reputational damage is likely to linger even after the truth is published. We take the view, however, that our approach strikes an appropriate balance between the claimant's Article 8 rights and the defendant's Article 10 rights, while also countenancing wider social goods. Pragmatically, some compromise of this nature seems essential to break the deadlock - both in principle and in public debate - over the design of a coherent libel regime.

\section{COMPENSATION FOR PROVABLE HARM}

While damages should not be available to vindicate/restore the claimant's reputation or for any unquantifiable presumed reputational harm, we take the view that the claimant should be able to recover in respect of any special damages that he or she can establish. No good reason exists to prevent the recoverability of such damages, and the danger that a substantial claim for special damages may have an unduly chilling effect is mitigated in part by the recognised difficulty of proving such loss. ${ }^{76}$ Abusive threats to litigate could be relatively easily dismissed on the basis of the power of the court to strike out any claim for special damages where it has no reasonable possibility of success. ${ }^{77}$

Where a claim for special damages is made, all of the defences currently available to the defendant could be relied upon. It would be for the adjudicator or court to determine whether the defamatory statement caused the damage complained of. Here again, meaning becomes less central to proceedings as the primary focus is placed on the reasonable foreseeability of the special damage in question, which in turn implies that it must be possible for particular meanings to have been reasonably inferred.

\section{Endpoint: a two-track libel regime}

Drawing the strands of the foregoing analysis together, it becomes possible to recommend a coherent set of significant substantive and procedural reforms that if enacted would enhance access to justice, simplify processes and reduce costs for the vast majority of libel actions. In essence, our proposal involves the recommendation of a two-track libel regime.

\section{TRACK ONE: SIMPLIFIED TREATMENT FOR THE MAJORITY OF CLAIMS}

The first track in this new regime would comprise a much-simplified process. It would involve the establishment of a new approach to libel actions that would emphasise the swift resolution of complaints and the provision of discursive remedies. This function could be retained by the High Court, but it might instead be administered by co-regulatory bodies designated under a new Defamation Act. This group could certainly include one or more self- or statutory media regulators for cases deriving from media publication. It may also

76 Special damage must actually have accrued before the claim was brought. Neither the apprehension nor the possibility of such damage is sufficient to give rise to a claim. By way of example, in Michael v Spiers and Pond Ltd (1909) 101 LT 352, it was held that a threat by the father of the claimant to remove him from his office as director of a limited company unless he could succeed in vindicating his character against the charge of drunkenness was not actionable because he had suffered no temporal loss; the claimant still had his office and the mere apprehension of its loss was insufficient to amount to special damage.

77 Civil Procedure Rules (CPR) (SI 1998/3132 as amended), r. 3.4(2). 
extend to expert professional panels for defamatory comments made in specialised contexts such as academic conferences, or independent arbitrators for the residue of other cases arising other than through media publication. ${ }^{78}$ The overwhelming majority of cases would be addressed solely by this route. The High Court could exercise a supervisory function, and review the first-track decisions of the designated bodies on the traditional grounds of illegality, irrationality, procedural impropriety and for compliance with Convention rights.

In this first track, the determination of the meaning of imputations would be much simplified by adopting the meaning(s) inferred by the claimant subject to a test of reasonableness. The single meaning rule would be withdrawn. Truth and honest comment would remain as the primary defences, while in appropriate cases the defendant would also be able to rely on absolute, traditional or statutory qualified privilege. The rationale underpinning the Reynolds public interest defence would disappear in respect of track one. Damages would only be available for psychological harms protected under Article 8 ECHR. The degree of harm would be allocated within one of three bands of award depending on the level of seriousness. The top band for exceptionally serious Article 8 harm would be capped at $£ 30,000$. Vindication would not be obtained by way of damages, but rather through an appropriate - and mandated - discursive remedy. Normally, this would be either a correction or retraction, although apologies could be mandated and declarations of falsity made where the claimant proved falsity. Rights of reply could be allied with any of the other remedies as deemed appropriate by the adjudicatory body. The remedy in damages for intangible harm to reputation would be withdrawn. Special damages for provable loss would be unavailable in this track. Recoverable costs would be limited. ${ }^{79}$ The approaches to substantive questions suggested here would very significantly reduce the complexity and cost associated with particular cases. Hence, it would reduce the chilling effect of the law on publication, and markedly enhance access to justice for defendants and claimants.

\section{TRACK two: Reference out to High Court For Serious libels}

The second track would be limited to aspects of the most serious and/or most damaging libels. Part of such cases would be referred out to this track only where the claimant sought special damages for provable loss or punitive damages, or where psychological harms protected under Article 8 are severe so that the track-one procedure would be manifestly inappropriate to deal with the case. It would also be open to a defendant to argue that the publication had raised a matter of real public interest. Those aspects of cases referred out to track two would continue to be heard in the High Court. Where proven by the claimant, special and punitive damages would be recoverable. Uncapped damages would be available for Article 8 psychological harm (although a de facto cap would remain by pegging to nonpecuniary damages recoverable for physical injury). A Reynolds-style public interest defence would be available in track two. Where the defendant relies on Reynolds, however, proper recognition of the underlying principles of freedom of expression and the importance of reputation require that the defendant provides either a right of reply or a notice of

78 There would be no reason why such an adjudicatory body need be established directly by the state. Provided any decision of an authorised adjudicatory body was subject to judicial review, a private sector corporation such as the Early Resolution CIC (a community interest company founded by Alastair Brett and Sir Charles Gray which provides arbitration and mediation services to determine some or all the issues in a libel claim could be left to determine track-one claims, and would be likely to do so very much more quickly and cheaply than the High Court does currently. Other entities could also apply to be allowed to offer adjudication of track-one claims. Thus, for instance, the Internet Service Providers Association might establish a dispute resolution body (the decisions of which would be subject to judicial review) which would be available where the claimant was libelled online.

79 As a manifestation of the overriding objective of the CPR (r. 1). 
correction with due prominence. Each party would carry their own costs with regard to those aspects of disputes referred out to track two.

\section{Conclusion}

A key benefit of adoption of the scheme outlined here would be to provide significant incentives for complaints to be settled quickly between the parties without recourse to the formal adjudicatory regime. We recognise that the availability of track two may continue to facilitate the abusive threat of legal action, but suggest - first - that claims to have suffered severe Article 8 harm or particular losses could be easily identified and quickly dismissed by the court if unsubstantiated and, second, that the revision to rules on the allocation of costs would mitigate this problem. We also recognise that the releasing of media defendants in most cases from the risk of very significant legal costs and damages may encourage "gameplaying" by some organisations. In our view, the blunt constraint currently afforded by high costs is adequately substituted by obliged dedication of space to accommodate discursive remedies and the loss of credibility that would go along with such repeated emphasis on poor quality journalism. We do not shy away from the fact that these remedies themselves involve interference with defendants' Article 10 rights "not to speak". We also note that discursive remedies afforded quickly are often the primary outcome that claimants seek.

Ultimately, it is our contention that only through the adoption of a radical revision to the law and procedures of libel such as is here proposed can the personal and social interests in expression, reputation and access to justice be properly valued and balanced. We fear that current proposals will serve instead to undermine personal and social interests in reputation, and allow untruths to perpetuate in the public sphere to the detriment of the wider understanding of matters of democratic importance. Simply precluding the possibility of litigation and redress - whether by withdrawing access to workable funding mechanisms so as to leave the option of litigation open to none bar a tiny minority of prospective claimants by dint of sheer cost, or by taking areas of subject matter entirely outside the purview of the law - is no way to design a libel law fit for a discursive constitution. 
